\title{
Batam Tourism Visits and Economic Growth: Policy and Impact
}

\author{
Albert Gamot Malau, Faculty of Science and Technology, Open University. Indonesia \\ April Gunawan Malau, Sea Transportation and Port Study Management Program The College of Shipping, Jakarta. Indonesia
}

\begin{abstract}
Purpose- This study was supported by an increase in the number of tourist visits, the number of hotel occupancy.

Design- The method used is 2SLS (Two-Stage Leas Square) by identifying simultaneous equations. Data processing using the computer program SAT.EST version 6.12. The Tourism Sector is very important as a source of foreign exchange-earners for Batam City.
\end{abstract}

Findings- This tourism sector has good potential to create job opportunities and business opportunities as well as to increase and even the income of the people and the region. Gross Regional Domestic Product greatly influences the Number of Tourist Visits, this can be seen by increasing the Number of Tourist Visits by 10, it will encourage an increase in the Gross Regional Domestic Product of the Tourism Sector by 19.91 units per year. The number of hotel dwellings increased by 10 units, will increase the number of tourist visits by 75894 units per year. Increasing the number of tourist destinations increased by 10 units, will increase the number of tourist visits by 20864 units, increasing the number of hotel rooms by 10 units will increase the number of tourist visits by 267 units, increasing the number of stays by 10 units will increase the number of tourist visits by 12420 units. If the Government carries out policies by adding tourist Destinations by 20 percent, it will directly impact the increase in Batam's Gross Regional Domestic Product by 2.44 percent, increase tourist visits to Batam by 1.7 percent, and If the Government conducts policies by increasing the number of hotels by 20 percent, will have a direct impact on increasing Batam's Gross Regional Domestic Product by 1.86 percent, and increasing the number of tourist visits to the city of Batam by 20 percent in the long run..

Originality/Value- Batam City is one of the cities flanked by three countries in Asia, this is a capital to increase the level of tourist visits to the City of Batam. This can be seen from Batam City's economic growth rate. Batam's Gross Regional Domestic Product increased by 10 percent in 2010. This article is original and has not been published in any journal. Keywords--- waiting time, turn round time, Bontang port.

\section{Introduction}

Batam City is a very strategic city in the Malacca Strait, directly adjacent to the Malaysia State and Singapore. This is one of the capital to increase the Economic Growth of Batam City. By Presidential Decree number 41 of 1973, regarding Batam Island, it is determined as an industrial area working environment supported by the Batam Island Industrial Development Authority or better known as the Batam Authority Agency (BOB) as the driver of economic development. The city of Batam reaches $1,038.84 \mathrm{~km} 2$ and the area of its waters is $2,791.09 \mathrm{~km} 2$. The economy of Batam City is not only the consumption of the people of Batam and Indonesia but also an export commodity for other countries. The existence of economic activities in the city is also in the context of increasing employment and public welfare. Batam City's economic growth in a country is measured by the difference in the Gross Regional Domestic Product (GRDP) of a certain year with the previous year. Economic growth followed by change (growth plus change). First the change in economic structure from agriculture to industry and services. Second, institutional changes, both through regulation and institutional reform itself (Kodrat Wibowo, 2012).

According to BPS (2018), the rate of tourist visits to Batam has increased in 2019 by 13\%, but in 2010 decreased by $7 \%$. The increasing number of tourist visits in Barenggi with the increasing number of hotels in the city of Batam. In 2010 the number of hotels increased by $6 \%$, this shows that Batam City has the potential to increase the economic growth of Batam City (Syamsul Baheum, (2010)). Therefore, it is necessary to increase investment more broadly in the context of the Batam City Tourism investment. Specifically, this study aims to (1) Analyze Tourism Visit Policy on Batam City Economic Growth (2) Impact of Tourist Visit on Batam City Economic Growth. 


\section{Literatur Review}

Todaro, Harrod-Domar (2000: 137) states that the process of economic growth development has three main components, namely: (1) Capital accumulation, which includes all forms or types of new investments that are invested in land, physical equipment, and human resources. (2). Population growth, which in the next few years will increase the number of the labor force (3). Technology advances. The second role is investment can increase the production capacity of the economy by increasing capital stock, meaning that investors will affect the supply side. According to Supriono (2017: 103) that Tourism destinations in the city of Batam are mostly dominated by local visitors han this is due to the location of these tourist destinations close to shopping places. The urge to travel is due to various interests both because of economic, social, cultural, political, religious, health and other interests such as simply being curious, adding experience or learning. Likewise according to Yeti (1996: 118) put forward the notion of tourism as a recreational activity which is held from one place to another with the intention not to try or make a living in the place visited, but merely to enjoy the trip for sightseeing and recreation or to fulfill desires diverse.

According to Pandit (1990: 30), Tourism is traveling these people can be described by many people who left their residence or home for a while to another place with the purpose of really as a consumer and completely without the purpose of making a living. Tourism is one aspect of human mobility. However, the difference in understanding of human mobility and tourism is only a pseudo-difference, not essential, especially in terms of the similarity of facilities and infrastructure needed. Thus various motivations for human mobility can also constitute tourism motivation, whether as a primary or a side motivation. According to the Director-General of Tourism (1976: 25). 10 Understanding the tourism industry according to Kusudianto (1996: 11), namely an organizational structure, both government and private sector involved in the development, production, and marketing of a service product that meets the needs of people who are traveling. Mathieson and Wall (1982: 46) say that tourism includes three main elements: Schulalard, in (Yoeti, 1982: 105) provides a tourism limit that is "Tourism is the sum of operations, mainly of an economic nature, which is directly related to the entry, stay and movement of foreign inside the certain country, city or region ". Thus the convention tour participants 'expenses also bring along their wives, children or even friends which have an impact on the participants' expenses while participating in cogency activities to be greater (Pendit, 1999). Some notions for MICE activities are linked to tourism activities. The main sources of economic growth from the expenditure side are household consumption and Gross Fixed Capital Formation (PMTB).

Investment can be defined as the addition of new capital goods (new capital formation) (Rosyidi, 2006: 185). Investment is one of the important components that can drive economic growth. According to Samuelson (1997: 173) investment has two roles in terms of macroeconomics. First, investment is a component of substantial and variable expenditure. Second, investment raises capital accumulation. Building several useful buildings and equipment, a country's potential output will increase and long-term economic growth will also increase.

The Islands Region is one of the destinations that provide different forms or types of tours from tours on broad land in general. Because the geographical conditions of the islands are very typical. Riau Islands in this case Batam Island has various types of tourism, which is an attraction in attracting tourists to come to visit. According to Palupessy (2011), states that integrated tourism areas take into account the centers of tourist activity, the characteristics of the type of tourism and have a connection with the tourist path in this case associated with tourism potential. The integrated tourism area in this study integrates various types of tourism in the Riau Islands, in this case, Batam Island and its surroundings, so that these types of tours support each other so that later they can support the main types of tourism located on Batam Island. Because the tourism sector is the largest contributor to the Batam regional gross domestic product, it is necessary to analyze the Tourism and Growth visit: Batam City's policies and impacts. (Figure 1).

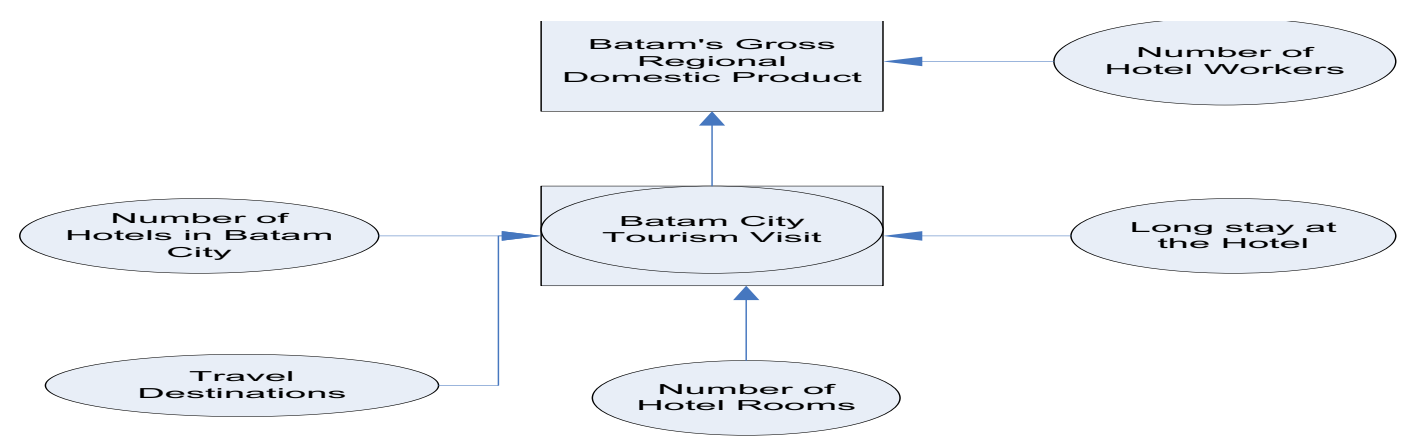

Figure 1. Framework for the Model of Tourism Visits and Economic Growth in Batam City 


\section{Methodology}

The study was conducted in Batam City in 2018, using time series data that began in 2006 - 2018. Data were obtained from the Central Bureau of Statistics, Central Bureau of Statistics of Riau Islands, Central Bureau of Statistics of Batam City, Department of Tourism of Batam City, Department of Tourism of Riau Islands, Ministry of Tourism. Impact Analysis and Tourism Visit Policy on Batam City Economic Growth, using the Econometrics Model. Understanding the framework of thought and literature review then formulated an econometric model that is expected to solve the research problem.

\section{Batam City Gross Regional Domestic Product (PDRBB)}

One of the variables expected to affect Batam's Gross Regional Domestic Product is tourist visits, the number of hotel workers, and Batam's Gross Regional Domestic product last year. Then the Gross Regional Domestic Product of Batam City with the exogenous variables that affect as follows:

PDRBB $_{\mathrm{t}}=\mathrm{a}_{0}+\mathrm{a}_{1} \mathrm{JKW}_{\mathrm{t}}+\mathrm{a}_{2} \mathrm{JPK}_{\mathrm{t}}+\mathrm{a}_{3} \mathrm{PDRBB}_{\mathrm{t}-1}+\mathrm{U}_{1}$

The parameters of the conjecture (hypothesis) are:

$\mathrm{a}_{0}, \mathrm{a}_{1}, \mathrm{a}_{2}>0 ; 0<\mathrm{a}_{3}<1$

Where :

PDRBB $_{\mathrm{t}}=$ Batam's Gross Regional Domestic Product in the t-year (million rupiahs) $\backslash$

$\mathrm{JKW}_{\mathrm{t}} \quad=$ Batam city tourism visit (person / year)

$\mathrm{JPK}_{\mathrm{t}} \quad=$ Number of Hotel Workers in the year $\mathrm{t}$ (people)

PDRBB $_{\mathrm{t}-1}=$ Batam Regional Gross Domestic Product last year (Million rupiahs)

$\mathrm{U}_{1} \quad=$ confounding variable

\section{Travel Visit (JKW)}

The variables that are expected to affect Batam City Visit are the number of hotels, number of tourist destinations, number of hotel rooms, length of stay, and number of tourist visits last year. Then the similarities of tourist visits are as follows:

$\mathrm{JKW}_{\mathrm{t}}=\mathrm{b}_{0}+\mathrm{b}_{1} \mathrm{JHT}_{\mathrm{t}}+\mathrm{b}_{2} \mathrm{DESW}_{\mathrm{t}}+\mathrm{b}_{3} \mathrm{JKM}_{\mathrm{T}}+\mathrm{b}_{4} \mathrm{MGR}_{\mathrm{t}}+\mathrm{b}_{5} \mathrm{JKW}_{\mathrm{t}-1}+\mathrm{U}_{2}$

The parameters of the conjecture (hypothesis) are:

$\mathrm{b}_{0}, \mathrm{~b}_{1}, \mathrm{~b}_{2}, \mathrm{~b}_{3}, \mathrm{~b}_{4},>0 ; 0<\mathrm{b}_{5}<1$

Where :

$\mathrm{JHT}_{\mathrm{t}} \quad=$ number of Batam city hotels in the year $\mathrm{t}$ (rupiah).

$\mathrm{DESW}_{\mathrm{t}}=$ Number of Batam City Travel Destinations (million rupiahs)

$\mathrm{JKM}_{\mathrm{t}} \quad=$ Number of hotel rooms in the year $\mathrm{t}$ (unit)

MGR $_{\mathrm{t}} \quad=$ length of stay at a hotel in the year $(\mathrm{t})$

$\mathrm{JKW}_{\mathrm{t}-1} \quad=$ Number of tourist visits last year (people)

$\mathrm{U}_{2} \quad=$ confounding variable

Model identification is a matter of model formulation rather than estimating or evaluating the model (Koutsoyiannis, 1977). The econometric model in the simultaneous form is said to be complete if the number of current endogenous is equal to the number of equations. Based on order conditions, an equation can be identified if the number of variables included in the equation is greater or equal to the sum of all endogenous variables minus one. The formula for identifying structural equation based on order condition according to Koutsoyiannis, (1977) is as follows:

$(\mathrm{G}-\mathrm{g})+(\mathrm{K}-\mathrm{k})>(\mathrm{G}-1)$ or $(\mathrm{K}-\mathrm{k})>(\mathrm{g}-1)$.

If the structural equations in the model are all over identified, then the equation can be estimated using the Two-stage square (2SLS), Three-Stage Least Squares (3SLS), Limited information maximum Likelihood (LIML) or full information Maximum Likelihood (FML) methods. The choice of method must be adjusted to the purpose of the study. Simultaneous estimation of parameters will help to simulate policy precisely and efficiently. Durbin-Watson statistics are invalid for estimating structural equations from the simultaneous equation model especially in the presence of endogenous variables on the right side of the structural equation.

To test whether the simultaneous equation model experiences serial correlation or not, the Durbin-h Statistical test (Pindyck and Rubinfeld, 1991) is used with the formula: 
$h=[1-0.5 D W]\left[\frac{T}{(1-T \cdot \operatorname{Var}(b))}\right]^{0.5}$

(4)

Where :

$\mathrm{H} \quad=$ Durbin-h statistical value

$\mathrm{T} \quad=$ number of sample observations

Var. (B) = the square of the standard error of the endogenous variable leg coefficient

D.W = Durbin-Watson statistical value

The Durbin-h statistical test is invalid if the value of var. (B) is greater than one. If the $h$ statistic is greater than the critical value of the normal distribution, then the model does not experience serial correlation. Statistical criteria that are often used to validate the estimated value of econometric models include Root Mean Square Error (RMSE), Pindyck and Rubinfied Root Mean Square Percent Error (RMSPE), (1991). These criteria can be formulated as follows:

$$
\text { RSMPE }=\left[1 / \sum_{i=1}^{T}\left(Y_{t}^{S}-Y_{t}^{a}\right)^{2} /\left(Y_{t}^{a}\right)^{2}\right]^{0.5}
$$

$$
\text { U- Theil's }=\frac{\left[1 / \sum_{i=1}^{T}\left(Y_{t}^{S}-Y_{t}^{a}\right)^{2}\right]^{0.5}}{\left[1 / \sum_{i=1}^{T}\left(Y_{t}^{S}\right)^{2}\right]^{0.5}+\left[1 / \sum_{i=1}^{T}\left(Y_{t}^{a}\right)^{2}\right]^{0.5}}
$$

The value of the Thein (U) inequality coefficient is between 0 and 1 . If $U=0$ then the estimation of the model is perfect if $U=1$ then the estimator of the model is naive. In essence, the smaller the value of RMSE, RMSPE, and $U$, the better the estimation of the model.

\section{Result and Discussion}

The method used is to use the 2SLS (Two-Stage Least Squares) method. The results of the evaluation of the presumptive parameters of the model indicate that most of the allegations of the presumptive parameters in each equation correspond to expectations. Overall the coefficient of determination (R2) is quite high and ranges from 0.5002 to 0.9607 , and the statistical probability value of $\mathrm{F}$ in all equations is real to very real ie the value ranges from 0.1141 to 0.0001 . T-test results show that in general the alleged parameters of explanatory variables in the model equation, some are not real and some are significantly different from zero at the real level $\alpha$ to 30 percent.

\section{Batam City Gross Regional Domestic Product (PDRBB)}

\begin{tabular}{|c|c|c|c|c|c|c|}
\hline No & $\begin{array}{c}\text { Variable } \\
\text { Explan } \\
\text { ation } \\
\end{array}$ & Estimated Parameter & Prob. $\mathrm{t}$ & Real level & SR elasticity & LR elasticity \\
\hline \multirow[t]{5}{*}{1} & PDRBB & & & & & \\
\hline & Intersep & $-4.9 \mathrm{E} 7$ & & & & \\
\hline & $\mathrm{LJKW}_{\mathrm{t}}$ & 60.70343 & 0.0842 & A & 0.15 & 1.22 \\
\hline & $\mathrm{JPK}_{\mathrm{t}}$ & 8754.596 & 0.2278 & $\mathrm{C}$ & 0.67 & 1.03 \\
\hline & LPDRBB & 0.068777 & 0.8917 & - & & \\
\hline
\end{tabular}

Batam's Gross Regional Domestic Product was affected by the number of tourist visits, the number of hotel workers, and Batam City's Gross Regional Domestic Product last year (Table 1)

Table 1. Estimation Results for Batam Gross Regional Domestic Product Equation Parameters 2007-2018

Note: $\quad \mathrm{A}=$ significant effect on the level $\alpha 5-10 \%$

$\mathrm{C}=$ significant effect on the level $\alpha 21-30 \%$. 
Batam's Gross Regional Domestic Product is positively related to the Number of Tourist Visits (LJKWt), the ratio of the number of hotel workers (JPK), last year's Batam Gross Regional Domestic Product (LPDRBB). All presumptive parameter signs are by expectations and variables have a significant effect. Estimation results show that the number of tourist visits increased by 10 units will encourage an increase in the Gross Regional Domestic Product of Batam City by 607 units per year. Increasing the number of hotel workers by 10 units will increase Batam's Gross Regional Domestic Product by 87545 units. Increased Batam's Gross Regional Domestic Product last year by 10 units only increased Batam's Gross Regional Domestic Product by 0.68 units. Overall the above results show that the number of tourist visits and the number of hotel workers contributed significantly to the formation of the city's Gross Regional Domestic Product Batam both short term and long term. The coefficient of determination $\mathrm{R}_{2}$ is 0.9907 meaning 99.070 units of variation of endogenous variables can be explained by explanatory variables included in the equation. Probability value $\mathrm{F}$ is equal to 0.0001 , meaning the explanatory variables together can explain the variation of GRDP. T-test results show that the number of tourist visits with explanatory variables is significantly different from zero at $\alpha$ 30 percent. Based on the elasticity value, the response of endogenous variables (GRDP) to all explanatory variables in the short term is inelastic ie it does not respond to changes in these explanatory variables. But in the long run, the variable number of tourist visits (elastic) to the change in the variable of Batam's Gross Regional Domestic Product.

\section{Tourist Visits (JKW)}

Tourism visits are hypothesized to be influenced by the number of hotel rooms, number of hotels, number of tourist destinations, length of stay, and number of tourist visits in the previous year. The estimation results of the Tourism Visit equation can be seen in (Table 2).

Table 2. Estimating Results For The Equation Parameters of Tourist Visits, 2006-2018

\begin{tabular}{|c|c|c|c|c|c|c|}
\hline No & $\begin{array}{l}\text { Variable } \\
\text { Explanation }\end{array}$ & Estimated Parameter & Prob. $\mathrm{t}$ & Real level & SR elasticity & LR elasticity \\
\hline \multirow[t]{7}{*}{2} & JKW & & & & & \\
\hline & Intersep & -183026 & & & & \\
\hline & $\mathrm{JHT}_{\mathrm{t}}$ & 7589.440 & 0.0710 & A & 0.05 & 1.00 \\
\hline & $\mathrm{DESW}_{\mathrm{t}}$ & 20864.83 & 0.6118 & - & & \\
\hline & JKM & 26.73749 & 0.3751 & - & & \\
\hline & MGRt $_{t}$ & 1242.050 & 0.2641 & $\mathrm{C}$ & 0.01 & 0,34 \\
\hline & $\mathrm{JKW}_{\mathrm{t}-1}$ & -0.12934 & 0.8755 & & & \\
\hline \multicolumn{7}{|c|}{$\mathrm{R}^{2}=0.94038 ;$ Adj. $\mathrm{R}=0.86884 ;$ Prob. $\mathrm{F}=0.0063$} \\
\hline
\end{tabular}

Tourist Visits (JKW) are positively related to the variables of Hotel Occupancy (JHT), Number of Tourist Destinations (DESW), Number of Hotel Rooms (JKM), number of lengths of stay (MGR), and Number of tourist visits last year (JKWt-1). JHTt and MGRt variables significantly affect the endogenous variables. The estimation results above indicate that if the number of hotel dwellings is increased by 10 units, it will increase the number of tourist visits by 75894 units per year. Increasing the number of tourist destinations increased by 10 units, will increase the number of tourist visits by 20.864 units, increasing the number of hotel rooms by 10 units will increase the number of tourist visits by 267 units, increasing the number of stays by 10 units will increase the number of tourist visits by 12420 units. The variable that gave the biggest contribution to the increase in the number of tourist visits was the variable hotel occupancy and the number of stays also made a large contribution to the endogenous variable. The variable number of tourist visits as the main variable that is thought to be able to contribute to the number of hotel occupancy and number of hotel occupancy. The coefficient of determination $\mathrm{R}^{2}$ is 0.94038 meaning that 94.03 units of variation of endogenous variables can be explained by the explanatory variables included in the equation. The probability value $\mathrm{F}$ is 0.0063 , meaning that the explanatory variables together can explain variations in the Number of Tourist Visits. Ttest results showed that the JHT and MGR variables were significantly different from zero at level $\alpha 1-30$ percent. The response of JKW endogenous variables to all explanatory variables is inelastic both in the short and long term 
Validation of Impact and Tourism Visit Policy on Batam City Economic Growth, 2019-2025

The simulation aims to analyze the impact and Tourism Visit Policy on the economic growth of Batam City. Before the simulation is done first the model is validated to find out whether the model is valid. Some statistical criteria used for validation are MSE, RMSE RMSPE, U-Theil, and $\mathrm{R}^{2}$. The expected MSE, RMSE, RMSPE and U-Theil values are small ie close to zero while $\mathrm{R}^{2}$ is close to one (Table 3). Equations that have a fairly large RMSPE (Root MeanSquare Satuantage Error) value namely the Gross Regional Domestic Product of Batam City and the Number of Tourist Visits This means that the estimated value of the five equations is not good. But the RMSPE value of the other equations is quite small. Besides RMSPE, the validity of the model can also be seen from the statistical value of UTheil. In this equation model, the U-Theil value is relatively small, which ranges between 0.01-0.9966. The existing coefficient of determination is mostly quite good at above 70 percent. The validation of each variable is historical by using secondary data for 10 years (2019-2027).

Table 3. Results of Validation of Tourist Visit Models and City Economic Growth Batam in 2019-2025

\begin{tabular}{|c|c|r|r|r|r|r|}
\hline \multirow{2}{*}{ No } & \multirow{2}{*}{$\begin{array}{c}\text { Endogenous } \\
\text { Variable }\end{array}$} & \multicolumn{2}{|c|}{ Basic Simulation } & \multirow{2}{*}{ RMSE } & \multirow{2}{*}{ RMSPE } & \\
\cline { 3 - 6 } & PDRBB & 6341280 & 86340370 & 3875841 & 8.9139 & 0.0131 \\
\hline & JKW & 1244771 & 1244774 & 74039.5 & 5.2111 & 0.0062 \\
\hline
\end{tabular}

Information: $\quad$ RMSE $=$ Root Mean Square Error

RMSPE $=$ Root Mean Square Percent Error

U-Theil = Nilai Koefisien Pendugaan Theil.

Before the simulation is carried out, the scenario that will be simulated is determined, the scenario is prepared with the aim of analyzing the extent of the policy and the impact of the Batam City Tourism and Economic Growth Visit and then taking several policies by the objectives of development and forecasting in 2019-2027. The aim is to carry out the policy of the Batam City Government for development in Batam City. The policy scenarios determined are as follows: (1) The policy scenario increases the number of tourist destinations by 20 percent, and (2) The policy scenario increases the number of hotels by 20 percent.

Policy by Increasing the Number of Tourist Destinations by 20 percent

To increase Batam City's GRDP, the government increased the number of destinations by 20 percent (Table 4)

Table 4. Policy Results of Increasing the Number of Tourist Destinations by 20 percent in 2019-2025

\begin{tabular}{|l|l|l|l|l|}
\hline $\begin{array}{c}\text { Endogenous } \\
\text { Variable }\end{array}$ & Basic Value & $\begin{array}{c}\text { Simulation } \\
\text { Scenarios.DESW } \\
\text { Naik 20\% Predicted } \\
\text { Mean }\end{array}$ & $\% \Delta$ & Label \\
\hline PDRBB & 86340370 & 88450380 & 2,448 & Batam Gross Regional Domestic Product \\
\hline JKW & 1244774 & 1265778 & 1,687 & Number of tourist visits \\
\hline
\end{tabular}

Source: data processed 2018

If the Government implements a policy of adding a tourism destination by 20 percent, it will have a direct impact on increasing Batam's Gross Regional Domestic Product by 2.448 percent, increasing tourist visits to Batam by 1.687 percent.

Policy by Increasing the Number of Hotels by 20 percent

To increase Batam City's GRDP, the government adopted a policy of increasing the number of Hotels in Batam by 20 percent (Table 5). 
Table 5. Policy Results of Increasing the Number of Hotels by 20 percent, 2017-2027

\begin{tabular}{|l|l|l|l|l|}
\hline $\begin{array}{c}\text { Endogenous } \\
\text { Variable }\end{array}$ & Basic Value & $\begin{array}{c}\text { Simulation } \\
\text { Scenarios JHT Naik } \\
\mathbf{2 0} \% \text { Predicted } \\
\text { Mean }\end{array}$ & $\% \Delta$ & Label \\
\hline PDRBB & 86340370 & 87950380 & 1,864 & Batam Gross Regional Domestic Product \\
\hline JKW & 1244774 & 1493581 & 20 & Number of tourist visits \\
\hline
\end{tabular}

Source: data processed 2018

If the Government makes a policy of increasing the number of hotels by 20 percent, it will have a direct impact on increasing Batam City's Gross Regional Domestic Product by 1.864 percent and increasing the number of tourist visits to the city of Batam by 20 percent in the long run.

\section{Conclusion}

Batam City's Gross Regional Domestic Product was affected by the number of tourist visits, the number of hotel workers, and Batam City's gross regional domestic product last year. The number of tourist visits and the number of hotel workers is very responsive affect the Gross Regional Domestic Product of Batam City. this shows that the higher the number of tourist visits, the Batam Regional Gross Domestic Product is higher, but the number of hotel workers does not stimulate the Batam Regional Gross Domestic Product. The number of tourist visits is influenced by the number of hotels, number of destinations, number of hotel dwellings, length of stay, average tourist expenditure, and number of tourist visits in the past year. The number of hotel dwellings is very responsive in both the short and long term greatly influencing the number of tourist visits. If the Government implements a policy of increasing the number of hotels by 20 percent, it will have a direct impact on increasing Batam's Gross Regional Domestic Product by 1.864 percent, and increasing the number of tourist visits to the city of Batam by 20 percent in the long run. If the Government makes a policy of increasing the number of tourist destinations by 20 percent, it will have a direct impact on increasing Batam's Gross Regional Domestic Product by 2.448 percent, and increasing the number of tourist visits to Batam by 1.687 percent in the long run.

\section{Acknowledgement}

This literature research result paper is part of research activities funded by 2019 Research Grant Of Open University Indonesia and Sea Transportation and Port Study Management Program The College of Shipping, Jakarta. Correspondent author : albert@ecampus.ut.ac.id

\section{References}

[1] Abdul Holik, (2016). Relationship of Economic Growth with Tourism Sector. Journal of Economics and Policy. Vol 9 (1) (2016): 16-33.

[2] Ayupuji, S.W. 2015. Factors that Influence Tourist Visits in Various Attractions in Mojokerto Regency, E-Jurna Unesa Vol 1 No 12015

[3] Albert. J. Strydom, (2017) Economic sustainability guidelines for a Community-Based Tourism Project: The Case of Thabo Mofutsanyane, Free State Province. African Journal of Hospitality, Tourism and Leisure 6 (2)

[4] Arief Daryanto, 2012. Quantitative Model Models for Regional Economic Development Planning, IPB Press 2012

[5] Azzah Fauziyah Choli, (2019). Sharia Tourism Development Strategy In Natural Recreation Sites Of Batu City, East Java. International Journal of Applied Sciences in Tourism and Events. Vol 3 No. 12019

[6] Central Bureau of Statistics. 2017. Riau Islands Province Economic Report. Central Statistics Agency, Riau Islands.

[7] Batam City Statistics Agency, (2018) Batam in Anggka 2018. Central Statistics Agency, Batam City

[8] Fitriani, E., (2016, December 21). Tourism Foreign Exchange Will Exceed Target. Accessed from http://www.beritasatu.com/ekonomi/4 05823-foreign exchange-tourism-will-past-target.html 
[9] Femy N., et.al (2013). The Influence of the Number of Tourism Visits, Number of Tourism Objects and Per Capita Income Against Tourism Sector Revenue in Kudus Regency. Diponegoro Jouranal Of Economics Volume 2 Number 2 Year 2013 Page 1-9.

[10] Minister of Tourism Establishes "Great Batam". (2015, January 15). Copy Editor. Antaranews.com.http: //www.antarakepri.com/berita/316 60 / minister-tourism-set-greatbatam

[11]Bellante, D. and M. Jackson. 1990. Labor Economics. Universitas Indonesia Publisher Institute, Jakarta.

[12] Dawan, M. R. 2003. The Role of Workers in Economical Development. Journal of Economic Reform, 4 (1): 51 70.

[13] Djuhari, M. 1999. The Shadow of Classical Economics. Directorate General of Higher Education Ministry of Education and Culture, Jalan Pintu Satu Senayan, Jakarta.

[14]Faried, W. M.1990. Introduction to Economics: Micro Economics. BPFE Publisher - Yogyakarta, Yogyakarta.

[15] Hary H. 2016. Impact of Nglanggeran Tourism Village Development on the Economy of Local Communities. Jurna Tourism Volume 3 Number 2 of 2016

[16] Koutsoyiannis, A. 1975. Modern Microeconomics. McMillan Press Ltd, London.

[17] Koutsoyiannis, A. 1977. Theory of Econometrics: An Introductory Exposition of Econometric Methods. McMillan Publisher Ltd, London.

[18] Kadek.K.R (2020) Effects of Tourist Visits and Tourist Attraction Revenues on Poverty in Regencies / Cities in Bali Province. E-Journal of Development Economics, Udayana University Vol.7. No. 10 October 2018

[19] Manning, C. 2000. Labor Market Adjustment to Indonesia's Economic Crisis. Indonesian Economic Studies Bulletin, 36 (1): 105-136.

[20] Mohd. Nur Syechalad. (2014). Factors That Influence Tourist Visits to Sabang City. Journal of Economics Postgraduate Syiah Kuala University, Volume 2, No. 4, November 2014

[21] Nurul N. 2018. Development of Islands Tourism Destination Areas in Batam City. Seminar on the Indonesian Built Environment Researchers Association (IPLBI) 3, A087-091.

[22] Raja R.A.P. (2013). The efforts of the Batam City Tourism and Culture Office in Shopping Tourism Activities in the Riau Islands (A Qualitative Study). Travel Destination Journal Vol 1, No. 12013

[23] Sutedjo, A and Sri Murtini. (2007). Tourism Geography. Surabaya: Unesa University Press

[24] Simanjuntak, P. (2000). Pengatar Human Resource Economics. Faculty of Economics Publisher Institute, University of Indonesia, Jakarta.

[25] Soekadijo. (2002). Anatomy of tourism (understanding tourism as "systemic linkage"). Jakarta: PT Gramedia main library

[26] Supahrmoko, M. (2002) Development Economics. Publisher of the Faculty of Economics Yogyakarta, Yogyakarta.

[27] Sukirno, S. (1985) Development Economics: Processes, Problems and Policy Basis of the Faculty of Economics, University of Indonesia, Jakarta.

[28] Sukirno, S. 2006. Introduction to Microeconomic Theory Second edition. PT Raja Grafindo persada, Jakarta

[29] Supriono 2017. Analysis of Description of Batam City Tourism Potential in order to attract foreign tourists. Journal of Applied Tourism, Volume 1 Number 2 of 2017

[30] Todaro, P. M. (1978). Urban Job Expansion, Induced Migration, and Rising Unemployment. Agricultural Development Council, Teaching Research Forum, (14): 1-15.

[31] Todaro, P. M. (1998). Development Economics in the Third World. Translate. Erlanga, Jakarta. 